Francisco VAz da Silva

\title{
The Invention of Fairy Tales
}

Ruth B. Bottigheimer has contended that a specific literary man invented the fairy-tale genre less than five centuries ago. This article is a critical examination of her claim. It interrogates the axioms underlying Bottigheimer's proposition, probes the logical consistency of her account, and surveys Bottigheimer's use of empirical evidence. It concludes that while Bottigheimer's proposition is a healthy challenge to folklorists who would disregard literary texts as a matter of principle, her assumptions, reasoning, and conclusions leave much to be desired.

RUTH B. BOTTIGHEIMER RECENTLY devised an imaginary biography—or, in her own words, "a biography of surmise" grounded in "historical record" - of the sixteenthcentury Italian author known as Giovanni Francesco Straparola (2002:3). In Fairy Godfather: Straparola, Venice, and the Fairy Tale Tradition, Bottigheimer endeavored to identify contextual "hints" in Straparola's primary work, Le piacevoli notti (Pleasant nights), and to associate them with the history of Renaissance Venice in order to "create a possible, probable, perhaps even a plausible biography for a man about whose life little is known" (2002:3). Of course, a biography of surmise that professes no greater standard of accuracy than being perhaps even plausible is one that grants to its compiler a considerable scope of creative freedom. The following discussion examines one central issue that underlies Bottigheimer's biographical endeavor: her claim that Straparola is the inventor of the fairy tale.

\section{The Problem}

Bottigheimer justifies the license that she grants herself on the grounds that Straparola accomplished a deed deserving of recognition: "Providing a life history, if only a possible or a probable one, is small recompense for the man who invented the wildly popular and wildly beloved plot of rags-to-riches-through-magic-andmarriage" (2002:44). Bottigheimer wishes to extol this man, whose life is "a nearly blank sheet" (45), for the one thing that she appears to be sure about in regard to his deeds-the notion that Straparola invented fairy tales. But how would she know this? The issue is intricate, and therefore this article scrutinizes Bottigheimer's claim from a number of angles.

Francisco Vaz Da Silva is Assistant Professor of Anthropology and Folklore in the Department of Anthropology at the Lisbon University Institute

Journal of American Folklore 123(490):398-425

Copyright $(\odot 2010$ by the Board of Trustees of the University of Illinois 


\section{An Imaginary Biography}

To understand the implications of resorting to "hints buried in Pleasant Nights itself" (Bottigheimer 2002:3) to construct the biography of a virtually unknown individual, consider this example. Bottigheimer asserts that the tale of "Fortunio" (night 3, story 4) "provides important clues about a psychological calamity" that took place during Straparola's youth. This claim hinges solely on the presumption that Fortunio's childhood in the most distant parts of Lombardy may be construed as an accurate description of Straparola's own childhood in Caravaggio; Bottigheimer declares Fortunio's tale to be "emblematically autobiographical." On this basis she imagines "Straparola's mother as worthy and amiable, the father as not well off, but presenting good qualities of head and heart," and she envisions Straparola himself as a distraught young man leaving home after he learns that he is a bastard (52-3). ${ }^{1}$

However, "Fortunio" is but one version of a pan-European story, tale type ATU 316 ("The Nix of the Mill-Pond"), and the hero's problematic birth is a staple feature of this tale type. (I discuss this matter in more detail below.) Therefore, it is arguable that Bottigheimer conceives Straparola's coming-of-age experience after the wondertale template of the hero's departure into the wide world. Perhaps this replacement of elusive biographical data with a fairy-tale motif has been facilitated by the fact that Straparola's given name was (in various accounts) Giovanni, Giovan, or Zoan-names that, like João, Jean, Hans, or Ivan, fit the pattern of the standard name for the European wonder-tale hero. At any rate, it is clear that the hero of Bottigheimer's story follows the wonder-tale life pattern when he leaves home in dramatic circumstances and then performs a stupendous feat-to wit, the invention of fairy tales.

It might appear that the invention of fairy tales does not match such wondrous deeds as sowing a field and then reaping and thrashing its grain all in one night or emptying a lake with a bucket and then catching all of the stranded fishes. But consider this: in Bottigheimer's analysis, the thirteen or so magic tales that Straparola included in Le piacevoli notti supposedly grew into the whole of the European fairy-tale tradition within about 250 years. And, if this still does not seem extraordinary, keep in mind that, according to Bottigheimer, the whole process happened only through literary channels. She presents the metaphor of a wondrously prolific, literary-based "vine" able to yield the "fruits" of the entire modern fairy-tale tradition from the meager "roots" of about thirteen stories-surely a suitable match for the magically productive tables and beanstalks of wonder tales: "[W] e may think of the trunk and branches as print dissemination and the fruit as individual oral performances of that print tradition. Like the vine, folk narrative is an organic entity, expanding over time in all auspiciously receptive directions and producing prolifically thriving and abundant results" (1993:279). In short, one gathers from Bottigheimer's biography of surmise that she frames Straparola's feat after the pattern of the narrative genre her hero purportedly invented. Bottigheimer's Straparola resembles a fairy-tale hero inventing fairy tales. This circularity is hardly surprising, for logical loops are typical of imaginary stories dealing with origins - and as will become clear, Bottigheimer's narrative is basically an origin tale, complete with variants. 


\section{An Article of Faith}

Bottigheimer frames her story of fairy-tale origins as historical scholarship. Her basic proposition is that Straparola invented fairy tales and then other literati, such as the early-seventeenth-century Italian author Giambattista Basile and various seventeenth-century writers of contes de fées, expanded this legacy quite apart from oral tradition. Indeed, it is axiomatic to Bottigheimer that fairy tales were not authored in the context of oral tradition; rather, as she claims in an early article, they were "disseminated to country folk" (1994:282). In an article published eleven years later, Bottigheimer states that these literary tales "ultimately nourished Europe's hungry folk imagination" (2005:27). This folk "hunger" for literary provender, which only the privileged classes could provide, clearly indicates the ideological backbone of Bottigheimer's account. In a 2006 article, she explains that the tales invented by Straparola were nurtured within the upper social classes and "only much later" moved to the folk (2006:217). Thus, Bottigheimer consistently claims that fairy tales were not common among the folk before the nineteenth century and that the oral traditions folklorists collected at that time had been only recently put in place via print pathways, including elementary-school readings. From this perspective, she reasons, the existence of similar tales in geographically distant locations becomes readily understandable. Indeed, the fundamental stability of fairy tales is readily explained if each orally collected tale "was probably only one, two, or at the most three steps away from a book source” (2006:217). "[E] ach logical impediment for understanding fairy tale dissemination," she claims, "disappears when a literate author replaces an anonymous folk as responsible fairy tale author and when printed books replace human mouths as the route of fairy tale dissemination" (220).

The essence of Bottigheimer's argument is that the "folk" as a whole cannot author fairy tales and that, as is clarified by the vine metaphor, the oral tradition is only the end or the "fruit" of a process of invention and transmission by literary means. This stance draws on Albert Wesselski's theory-formulated in the 1920s and 1930s and rejected at that time-that the book has been the main means of dissemination for folk narratives. ${ }^{2}$ In contrast, specialists in oral tradition have long realized that the workings of transmission in folklore are based on individual creativity within a conventional framework (Jakobson and Bogatyrev [1929] 1982; cf. Dégh 1995; Foley 1988; Goody 1977, 2002; Lord 2000). If repetition and authorship come together in oral transmission, then the very notion of a first-time author becomes useless. Arguably, it is as futile to search for the inventor of fairy tales as it is to seek for the author of language, the creator of mythology, or the architect of religion. Nevertheless, Bottigheimer remains true to the postulate that the "hungry folk imagination" needs "literary provender," ${ }^{3}$ which only the privileged classes can provide, and her story about the invention of fairy tales unfolds from this article of faith.

\section{Strange Premises}

Let us look at premises. Again, the foremost question that springs to mind is: why would Bottigheimer think that she found the inventor of fairy tales? By her account, 
the matter is straightforward. Since Straparola's Le piacevoli notti contains the first set of printed European fairy tales, Bottigheimer concludes "that Straparola himself invented the previously undocumented tales" (2002:2). This is an astounding proposition, for it explicitly assumes that the absence of earlier printed evidence amounts to evidence for the absence of earlier versions of the tales. This is analogous to saying that a lack of empirical evidence for invisible matter rules out the existence of microscopic entities or that a lack of evidence for inaudible sounds precludes the possibility of sound in frequencies above or below human hearing. Generally speaking, the presumption that absence of evidence is the same thing as evidence of absence encourages people to stick to the illusory simplicity of appearances instead of seeking to understand more complex layers of reality.

Bottigheimer defends her claim in the following terms:

\begin{abstract}
"[T]he absence of evidence is evidence of absence." By that I meant that the absence of evidence (of the existence of a tradition of passing fairy tales on orally) is evidence for the absence (of the existence of that tradition). Oralists have proposed some initially appealing refutations. For instance, if a tree falls in the forest but no one hears it, was there a sound? ... In the field of folk narrative a parallel statement of this philosophical conundrum would be: Is a tale heard when it is told in the absence of a listener? Here common sense tells us that only its teller hears the tale, which is, of course, irrelevant for questions of dissemination. Thus, in my opinion, the proposition that the absence of evidence is evidence for absence continues to stand. (2007a:19)
\end{abstract}

Let me first refute a fallacy in this argument. The falling-tree analogy addresses the discontinuity between an event in oral tradition and the awareness that literati may (or may not) have of that event; it is not an issue of whether or not a tale is heard when it is told in the absence of any listener. The point is that if a story is told and retold but no one ever puts it down in writing and the memory of it eventually fades along with the people who heard and told it, then, from the remote point of view of literary scholars (but only from that limited point of view), the story will never have been heard. Aural transmission, whereby stories are preserved in living memory, is intangible from the point of view of hard print sources. It follows that one cannot settle the status of a given theme in aural transmission by means of the date of its first appearance in written documents. Incidentally, the oldest known written source for a given theme is just that - the oldest known written source-for other print versions may have been lost or may remain unknown. One simply cannot decree that the oldest known source for a theme is the first of its kind.

This misapprehension regarding the nature of oral tradition is compounded by a basic factual error. As we saw, Bottigheimer (2006:217) claims that each orally collected tale was probably only one, two, or at the most three steps away from a book source. But the present state of knowledge-as displayed in the fourth revision of the catalogue of international tale types, the vade mecum of folktale research (Uther 2004) - strongly suggests that most oral fairy tales have no match in known literary sources. Consider this rough estimate: among 270 plots classified as "magic tales," the catalogue of international tale types presents some 33 literary tale versions that were published between Straparola's lifetime and the nineteenth century. ${ }^{4}$ This sug- 
gests that Straparola, along with all of his presumed literary emulators, could have authored only about 12 percent of all the oral plots classified under tale types 300 through 749. Obviously, such a vast disproportion should preclude maintaining that the great ocean of oral magic tales has been authored by writers and disseminated via print pathways. How could the relatively scant printed matter have fed the vastly richer oral traditions found throughout the Indo-European realm and beyond?

And, of course, the elitist notion that literary fairy tales have been provender for the hungry folk imagination is problematic. Bottigheimer never ventures to explain why people in traditional settings should be unable to create and transform magic tales. Moreover, she disregards the fact that folklorists often found their treasure troves of tales among illiterate communities. Linda Dégh, for example, points out that in her ethnographic experience in Hungary, "villagers unanimously pointed to the district ... where the poor resided, as the hotbed of the magic tale" (1996:xvi). Dégh specifies that these individuals "were badly educated; many were illiterate, and conditions made school attendance difficult" ([1969] 1989:25). One exceptionally gifted narrator whom she followed closely, Zsuzsanna Palkó, "never learned to read and write, and never went to school” (Dégh 1996:xviii). Pierre Jakez Hélias reports a similar scenario in Brittany, where in his experience fairy-tale tellers were "de bien pauvres bougres" (quite poor devils), most of them being "des necéssiteux, des mendiants" (impecunious ones, beggars); Hélias notes in particular a blind beggar who often recounted stories to the Breton folklorist François Luzel (Hélias 1990:217). Such examples could be multiplied, but I will sum up here by pointing out that Bengt Holbek's analysis of extant empirical evidence concludes with the observation that "fairy tales always were told mainly among the poor" ([1987] 1998:151), which concurs with the ancient setting that Apuleius chose for the telling of "Cupid and Psyche." (Discussed more fully below, this tale is an important testimony to pre-Straparola fairy tales.) As Jan Ziolkowski puts it, "Apuleius ... emphasizes that the tale was told orally by the basest of base creatures, one portrayed cruelly in ancient art as well as literature-a raving, drunken old woman who serves criminal outcasts" (2002:92-3). In Apuleius's description, as well as in the experience of folklorists and ethnographers, fairy tales have consistently been the lore of the illiterate, downtrodden segments of society-hardly ideal candidates for the widespread reception of printed material.

In saying this, I acknowledge that chapbooks have long been in circulation among the folk and that the literate few among the folk have conveyed the contents of these books to the illiterate many. Still, as we saw, most oral tales lack literary matches. And conversely, only a tiny percentage of literary stories ever become oral traditions. As Holbek notes, if folklore depended exclusively on literary sources, then we should expect the tales of Perrault, the Grimms, and Hans Christian Andersen to be more or less evenly represented in oral tradition-but they are not. Some of these authors' tales made a very limited impact on oral tradition, and there are hundreds of orally collected variants that cannot be derived from their texts (Holbek [1987] 1998:253). This point brings to mind Roman Jakobson and Petr Bogatyrev's remark that tales must be selectively appropriated by a given community before they make their way into folklore ([1929] 1982:37). Regarding French fairy-tale themes appropriated into Native American traditions, Claude Lévi-Strauss proposed that Native Americans 
selectively borrowed those themes that appeared to them as variations on their own lore (1991:259-60). ${ }^{5}$ This idea, that oral traditions tend to borrow alien versions of their own themes, can help to explain why the intense circulation of chapbooks in European cities and villages did not lead to the wholesale adoption of all literary inventions into oral traditions. It is most reasonable to think that in chapbooks, readers and audiences found new versions of tales with which they were previously acquainted by other means (see also Catherine Velay-Vallantin's arguments in Seifert, Velay-Vallantin, and Bottigheimer 2006:279-80). ${ }^{6}$

However, Bottigheimer is adamant that intercommunication between literary channels and oral traditions can only mean that the former have generated the latter. Specialists in the history of European fairy tales have started to vent their unease with this stance. Velay-Vallantin complains that Bottigheimer's approach is "reductive" in comparison with the sophisticated understanding of the interplay between oral and literary tales developed by French researchers, and Lewis Seifert points out that Bottigheimer ignores a number of seventeenth-century allusions to oral fairy tales in order to jump to unwarranted conclusions about Straparola being the primary source for the literary contes de fées (Seifert, Velay-Vallantin, and Bottigheimer 2006:276-80). Unfortunately, these attempts to initiate a critical dialogue have been largely fruitless because Bottigheimer tends to remain ensconced within the logic of her own story. For example, she argues that even if there were women telling fairy tales in seventeenth-century France, they must have been using tales from Straparola because those were the only fairy tales available (Seifert, Velay-Vallantin, and Bottigheimer 2006:281). Such use of an unproven premise as a foregone conclusion in order to reassert the premise amounts, of course, to circular reasoning. This is a useful reminder that we are dealing with an origin story.

Thus far I have investigated the premises and outer layers of Bottigheimer's stance; I have not yet examined in detail the specific proposition that Straparola invented fairy tales and that other literati then diversified these tales and fed them into folklore. In order to take up this question more fully, the next section probes the inner consistency of Bottigheimer's story on the origin of fairy tales.

\section{The Thesis}

Why Straparola Invented Fairy Tales

In this section I will take up the question that has lurked in the background since the beginning of this essay: how would Bottigheimer know that Straparola invented fairy tales? Here is how she succinctly states her claim:

Straparola's role as an originator in the history of the modern fairy tale has been recognized only rarely ... and has been ignored for most of the twentieth century. For the majority of the Pleasant Nights stories he demonstrably borrowed heavily from prior Italian tale collections. In cases where published prototypes are unknown, literary scholars automatically invoke popular oral origins. My position diverges sharply [from this], for I have concluded, first, that Straparola himself invented the 
previously undocumented tales, and that he did so specifically for Venetian readers in the context of a generally faltering and occasionally recovering mid-sixteenthcentury economy; second, that his newly invented tales were the first to address the aspirations of an urban artisanal readership; and third, that his new rise plot both anticipated and precipitated that plot type in subsequent collections. (2002:2)

The leading ideas in this passage are that (1) Straparola himself invented the previously undocumented fairy tales in Le piacevoli notti; (2) such tales addressed the sinking hopes of an urban artisanal readership, presumably by means of the new "rise plot"; and (3) the newly invented tales cast Straparola as an originator in the history of the modern fairy tale. ${ }^{7}$ All three assertions are open to doubt.

First, as noted above, the claim that Straparola must have invented the fairy tales for which no previous print source is known presumes that the absence of printed evidence amounts to evidence of absence. But, again, aural transmission is intangible from the point of view of hard print sources. For this reason, one cannot settle the question of the existence or lack of existence of a given theme in mouth-to-ear transmission by means of the date of its first appearance in written documents.

Second, the statement that Straparola invented the previously undocumented tales specifically for Venetian readers roots Straparola's "creation" in the historically specific urban reality of Venice. Indeed, Bottigheimer stresses that Straparola's invention of "a magic-mediated marriage as an imaginary escape from the all-too-real miseries of poverty" was meant for a "passive and powerless sixteenth-century urban apprentice and artisan readership." As she puts it, the new genre's depictions of poor fellows escaping the all-too-real miseries of poverty were "literary provender" for an urban public "hungry for promises of a better life" (2002:17). Elsewhere, however, Bottigheimer more broadly states that Straparola's fairy tales "ultimately nourished Europe's hungry folk imagination" (2005:27), and she affirms that "fairy tales were associated with upper social classes in the sixteenth and seventeenth centuries" (2006:217). If there is a congruence between plot success and the preoccupations of the audience, then why would tales crafted for the specific situation of an urban Venetian readership become the characteristic lore of illiterate rustics across Europe and beyond? And why would tales offering imaginary escape from all-too-real poverty register success among the upper classes? Clearly, the principle of reference to social reality, which Bottigheimer uses to explain why a rise plot should have been successful in sixteenth-century Venice, fails to explain the reception of urban rags-to-riches plots among illiterate rustics as well as among aristocrats. In other words, the principle that is used to account for the invention of the genre fails to account for its diffusion.

Third, Bottigheimer's claim that Straparola invented a previously undocumented genre of narratives must be read in light of the notion that-by Bottigheimer's most recent count (see appendix below) - Straparola composed thirteen magic tales, of which only six register as "rise" stories. To explain the enormous gap between Straparola's two fistfuls of magic stories and the more than two hundred types of oral fairy tales identified in Uther's tale-type index-not to mention the many hundreds of stable variant plots-requires either allowing that new plots were created within oral tradition or proving that there has been a massive tale generation by literary means. 
Bottigheimer discards the first alternative, as she disavows the need to inspect "popular oral origins" in cases where published prototypes are unknown (2002:2). Indeed, this is a crucial assumption of her "book-based history of fairy tales" (2006:218-9). Therefore, Bottigheimer is left with the tremendous task of proving not only the transmission but also the inception of hundreds of new tales by literary means. Such a task is, of course, in accordance with Bottigheimer's constant emphasis on finding the publishing history of tales; so far, however, she has yet to provide the evidence that would support her claim.

\section{Book-Based History?}

Bottigheimer did provide an initial attempt to describe the publishing history of "The Lazy Boy" (ATU 675), as an example to "suggest print as the agent of conservation and the principal pathway of dissemination in the early-modern and modern world" (1993:275). The evidence that she found, however, is less than convincing. Bottigheimer's own candid assessment of her achievement is that

what I have written up to this point about print dissemination and print as a source for oral storytelling is based on circumstantial evidence. What is required is a completely documented trail which leads from a literary source through a chapbook popularization to an adoption by oral storytellers and eventual collection in the field. ... I have thus far not been able to establish an uninterrupted pathway for the "Lazy Boy" from literary creation to folkloric collection. (276)

While admitting that the "Lazy Boy" case remains inconclusive, Bottigheimer points to Stephen A. Mitchell's 1991 discussion of "Gråkappan," a Swedish form of the "Cupid and Psyche" / "Beauty and the Beast" cycle (ATU 425), to show that "such a pathway has been established for one Swedish tale long held to have been exclusively oral" (276). But this "complete life history" of the tale is actually rather modest, for it boils down to the hypothesis that "Gråkappan" - a tale that circulated widely in chapbooks during the nineteenth century and of which there are a few extant versions in Swedish folklore archives-was authored by the romantic writer Carl Jonas Love Almqvist and then entered into oral tradition (Mitchell 1991:270-8). Bottigheimer concludes, “This kind of evidence ... suggests that, at least in a country like Sweden, one need not look as much to other human informants for the 'correct' version of a story as to the wares of local colporteurs issuing from the Swedish print centers" (1993:277). I will leave aside the obvious point that one possible case of literary invention does not entail that all Swedish tales necessarily derive from written sources (and I refrain from commenting on the notion of a "correct version"). Instead, let me emphasize three things in regard to Bottigheimer's use of this example.

First, Mitchell does not actually suggest that the Swedish oral tradition derives from chapbooks. He acknowledges the persistence of the ATU 425 cycle "outside (or at least parallel to) the literary realm" (1991:274-5), and he recognizes that "Gråkappan does not belong solely to the realm of printed literature. ... the Swedish tales collected from folk tradition demonstrate that the story took on a life of its own in 
the repertoires of various narrators" (288). Mitchell's point is simply that "Gråkappan” has a literary origin, which grants him an opportunity to speculate on how the transitions from the printed medium to the oral medium may have happened (278). And his overall conclusion does not exactly suggest the ancillary status of oral tradition or the passive role of tradition bearers: "Despite their origins in a printed medium, the traditional multiforms of Gråkappan give ample testimony to the durability and vitality of the Swedish oral tradition, to the synthesizing capacity of that tradition, and to the sustained artistry of its raconteurs, as well as to the continued diversity of their artistic designs" (291).

Second, while there is no reason to doubt that Almqvist may have authored the chapbook text of "Gråkappan" (Mitchell 1991:273; Swahn 1955:112 n. 86), it is unclear what the "authorship" of a romantic literary figure rewriting a traditional theme amounts to. Mitchell acknowledges Almqvist's "proclaimed enthusiasm for the use of traditional materials as poetic resources," and he notes that Almqvist's tale is based on subtypes of ATU 425 and ATU 707, describing it as Almqvist's "reworking of" the ATU 425 theme. On the same page, however, Mitchell also states that Almqvist was "the author of it (albeit using many traditional motifs)" (1991:273). Here, Mitchell is using the word "author" in its full sense, implying that his version of the tale should be regarded as previously nonexistent in oral tradition. This assertion, however, involves a leap of faith.

Regarding the initial motif of "Gråkappan," which is common in the oral variants of this plot, Mitchell judiciously says that "facts of this sort lend themselves to two interpretations: it is perhaps as likely that Almqvist was using a traditional motif as it is that the device became traditional in Swedish oral literature through him, although the concatenation is suspicious" (1991:288). This remark, which allows that Almqvist may have used a traditional motif, could be equally applied to the "Gråkappan" plot as a whole. Moreover, Mitchell's illuminating discussion of four oral versions of "Gråkappan" suggests that while two of them were influenced by Almqvist's text, the other two "multiforms" owed little (if anything) to it (279-86). One might argue that Almqvist made use of a preexisting oral tradition (perhaps exemplified in the two collected oral versions of "Gråkappan" that were further removed from his text) and that his literary rendition of the theme then influenced some performances of the traditional tale (such as the two oral texts that bear clear influences from the "Gråkappan" chapbooks). Needless to say, this possibility in no way detracts from the value of Mitchell's nuanced case study and, in particular, from his insightful discussion of the interactions between a literary text and the creativity of traditional tellers.

The limited records of oral versions of "Gråkappan" make it hard to reach a firm conclusion about the significance of Almqvist's authorship. An analogous instance, however, based on more abundant data, could be more instructive. Many years ago, Paul Delarue (1951a) investigated the sources and the scope of the inventions of another writer bent on traditional materials, Charles Perrault. Delarue concluded that Perrault took "Riquet à la Houppe" (Ricky of the Tuft) from a literary source, that "La Belle au bois dormant" (Sleeping Beauty in the wood) is an intricate case requiring a separate study (see Soriano 1977:125-32), and that "Le Chat botté" (Puss in boots) is probably inspired by Straparola's "Costantino Fortunato," as well as by 
data from the French tradition. Furthermore, Delarue identified in French oral tradition three categories of tale versions that match the themes of Perrault's "Le Petit Chaperon rouge" (Little Red Riding Hood), "Le Petit Poucet" (Little Tom Thumb), "Cendrillon” (Cinderella), "Peau d'Ane” (Donkeyskin), "La Barbe bleue” (Bluebeard), "Les Fées" (The fairies), and "Le Chat botté": (1) those versions clearly derived from Perrault's texts via chapbooks and other literary works, (2) those versions showing traces of Perrault's influence and yet also showing independent traits, and (3) those versions bearing only independent traits and owing nothing to Perrault's text. This particular case study therefore suggests that the "authorship" of Perrault was rather more like a reworking of traditional materials that afterward made it back, in various degrees, into oral tradition. In a similar vein, Marie-Louise Tenèze (1973:47) has suggested that it is because the theme of ATU 333 ("Little Red Riding Hood") was alive in the French oral tradition that Perrault's text was well received by traditional tellers and thus influenced their repertoires (see also Holbek [1987] 1998:253; Seifert, Velay-Vallantin, and Bottigheimer 2006:279-80).

This brings me to my third point regarding Bottigheimer's attempts to identify bookbased histories: there is nothing new in the discovery of links between literary texts and orally collected tales. The sort of "trail" that Bottigheimer fails to find apropos "The Lazy Boy" has been known, regarding other tales, for quite some time. Although specialists have long been aware of the fact that Perrault's "Le Petit Chaperon rouge" had a sizable impact on modern French tradition, no one to date has jumped to the conclusion that Perrault started the oral tradition of this tale (see Bacchilega 1997:53-9; Delarue 1951b; 1951c; 1951d; 1953; [1956] 1980:380-3; 1985:381-3; Dundes 1989; Holbek [1987] 1998:253; Soriano 1977:140-60; Tenèze and Delarue 2000:102-11; Vaz da Silva 2002:113-43; Verdier 1997; Ziolkowski 2007:93-123; Zipes 1993:1-88).

In short, the acknowledgment that literary chains and oral traditions have often interacted does not lend credence to the one-sided pronouncement that literary texts are the sole source of fairy-tale traditions. Nor is it particularly clarifying when Bottigheimer resorts to vague mantras such as "questions of fairy-tale origins and transmission blur boundaries between the categories of 'oral' and 'literary' and illuminate the origins and transmissions of fairy tales" (2007c:11). (Incidentally, this is another example of circular thinking about origins.) The bottom line is that Bottigheimer has yet to present a study of publishing history that would provide the needed evidence in support of her contention.

\section{"Rise" and "Restoration" Tales}

So far, I have proceeded as if the meaning and scope of Bottigheimer's assertion that Straparola was "an originator in the history of the modern fairy tale" (2002:2) were clearly defined and transparent. Indeed, the meaning of "fairy tales" is fairly well established. In spite of various terminological fluctuations, nearly all folklorists would agree that wonder tales-also called magic tales, fairy tales, or Märchen-include plots that are mostly listed under tale types ATU 300 through ATU 749 in the international index (Uther 2004). Morphologically, these tales involve a shift into enchantment or the otherworld, followed by a subsequent return to the mundane world; as described 
by Vladimir Propp, this shift takes place through a stable string of thirty-one "functions" (Propp [1929] 1996; [1946] 1983:263). ${ }^{8}$ Therefore, Bottigheimer's task would seem straightforward-she simply needs to make a convincing case that (1) no such tales existed before Straparola and that (2) Straparola's thirteen or so magic tales indeed initiated the literary invention of the modern fairy-tale tradition.

But Bottigheimer has chosen to ignore previous scholarship and to reinvent definitions. Her stated reason is that "neither the motif-method nor the Propp-method is universally applicable" because of the "rarity of all-encompassing analytic systems." This rather cryptic statement is presented as evidence of the need for a "precisely delimited set of narratives" to deal with definition and history (1994:283). Unfortunately, far from creating precision, this is exactly where Bottigheimer's argument incites confusion, for her terminological innovation entangles the matter by framing it in terms of a dubious distinction between "rise" and "restoration" magic tales:

Fairy Godfather [Bottigheimer's 2002 book] grew out of a longstanding fascination with an arresting distinction between two kinds of magic tales, those that restore position and patrimony and those that record a rise from poverty to wealth. Tales of restoration revolve around social position lost through misfortune and restored by goodness, perseverance, courage, or magic. "Cinderella," despite the fact that its title and plot customarily stand for rags-to-riches tales, is a restoration tale, for its heroine began her life in comfort as the daughter of a rich man before she was thrust from her rightful place by spiteful stepsisters and stepmother. The happiness of the tale's ending depends on the fact that the heroine's restoration surpasses her original social and economic level.

Tales that I have come to call "rise tales" recount different stories altogether. They tell of heroes and heroines who began their lives in real poverty, but who achieve riches and attain a throne, catapulted upward by a marriage mediated by magic. (Bottigheimer 2002:1)

The contrast that is established in this passage between "rise" and "restoration" tales is undermined the very moment it is stated. Bottigheimer claims that "Cinderella" is a "restoration" tale in which the heroine surpasses her original social and economic situation. Logically, an increment in standing bespeaks rise, not merely restoration. Still, Bottigheimer defines the "Cinderella" story as a restoration tale-in spite of acknowledging a rise pattern in it-because the heroine does not start from rags. ${ }^{9}$

This inconsistency is telling, for it reveals that Bottigheimer is not really paying attention to plot; rather, she is focusing on motif. Indeed, it is her longstanding view that "rise" tales imply "an escape from class-defined poverty" (1994:286) and, therefore, "all have poor folks as their protagonists" (2002:9). In contrast, what defines the heroes and heroines of "restoration" stories is that they "begin life amid wealth and privilege" (2002:11). The relevant difference between "rise" and "restoration" tales therefore hinges on motif-initial rags versus initial wealth-and not on plot. And yet the novelty of rise tales is supposedly morphological. Bottigheimer acknowledges that "individual motifs familiar from modern fairy tales existed in the distant past," and she insists they had to "agglomerate" in order to produce "coherent fairy tale stories" (1994:283-4). This amounts to saying that Straparola's invention concerns 
plots rather than motifs. We can therefore see that there is a discrepancy between Bottigheimer's morphological definition of the rise/restoration dichotomy and her handling of it in the analysis of the empirical data. In other words, Bottigheimer fails to consistently use her own distinction.

Therefore, one has to ask whether there are grounds for making the rise/restoration distinction in the first place. Although the difference between "rise" and "restoration" tales apparently concerns morphology, a glance at the basics of wonder-tale morphology shows that the initial lack afflicting the heroine or hero can take a number of guises. The deprived heroine or hero might be a last-born child, or an orphan, or a dullard; poverty is but one of many ways to convey lack. Therefore, it makes about as much sense to separate plots according to whether the heroine or the hero is initially rich or poor as it would to distinguish plots according to whether he or she is dimwitted or bright or whether he or she is a beloved child or a neglected stepchild.

Propp long ago remarked that the functional axis of fairy tales proceeds from lack toward fulfillment and that the journey along this axis hinges on obtaining something precious from the otherworld (Propp [1929] 1996:92, 107; cf. [1946] 1983:263, 37193). Thus, plots consistently depict the main character's fall into a liminal situation involving symbolic death or enchantment, ${ }^{10}$ followed by his or her consequent rise to a newly exalted position. In other words, all fairy tales follow a pattern of fall and rise even while charting a net increase between the initial and final situations. This belies both the notion of a simple "rise" (insofar as there is a fall) and the notion of a simple "restoration" (insofar as there is a net increase). While fairy tales hinge on the initiation pattern of a fall into enchantment/death as a means for rebirth into a higher sphere of life, Bottigheimer reads them from the contemporary materialistic vantage of social station and economic status-which simply misses the point.

If these remarks are accurate, then the "rise" pattern should not readily befit Straparola's magic tales. Bottigheimer acknowledges that this is precisely the case. With perhaps a tinge of euphemism, she admits that "some of Straparola's tales deviated slightly from" the rise trajectory. However, she lays the blame at Straparola's door: "When one considers that Straparola can be said to have been practicing a new genre of sorts, it is not surprising that he tried different narrative routes to marriage and wealth. By the time he wrote his last rise tale, 'Costantino and His Cat,' he had worked out the formula that would guide modern rise tales" (2002:27). In a similar vein, Bottigheimer recognizes in "Fortunio" (night 3, story 4) both a rise and a restoration tale because, "in his early rise tales, Straparola had not yet distinguished them as a separate genre" (22). But, again, this sort of explanation amounts to circular reasoning. Bottigheimer uses the notion that she wishes to establish—namely, that Straparola invented "rise" tales—as a foregone conclusion to explain why many of Straparola's tales are not fully pliant to the "rise tale" definition. Her avowal that it was only when Straparola wrote his last tale that he perfected the rise formula implies that only one text in Le piacevoli notti really fulfills Bottigheimer's definition of what rise tales ought to be.

One final observation should be made regarding the problematic nature of the rise/ restoration distinction. Bottigheimer asserts that Straparola's "great and lasting contribution to the European literary heritage" was "to have invented rise tales" (2002:2) — or, more exactly, "the rise tale plot" (6). She also claims that restoration plots had been 
extant in "courtly romances and magic tales" during the medieval and early modern periods (5), and she assumes that Straparola abbreviated these medieval romances into more linear plots to create the stories that she categorizes as his "restoration tales." Summarizing her view in a February 5, 2007, e-mail message to me, Bottigheimer wrote that "Straparola invented what we in the modern world call 'fairy tales,' by abbreviating medieval restoration romances and by creating the rise fairy tale." Bottigheimer also acknowledges, however, that rags-to-riches plots hinging on "wit or happenstance" actually preexisted Straparola (2002:14). The novelty of the rise-plot creation could therefore only reside in the blending of preexisting magic themes with preexisting rags-to-riches plots. Indeed, as Bottigheimer allows, Straparola's "new kind of story. . . combined the urban tale's humble protagonists with the courtly tale's magic" (5). So, then, everything-fairy-tale magic motifs, "restoration" plots, and rags-to-riches plots-was already in place. The only thing lacking, apparently, was the idea of having magic-tale heroines and heroes start from dirt poverty. As was mentioned earlier, however, poverty is but one of several possible ways to convey lack in fairy tales. This means that whether or not heroes and heroines start out from rags is a variation trait — an allomotif, as Alan Dundes (1987) would say—and not a structural feature. Therefore, the criterion of social station cannot be used even to distinguish among variants of a given tale type, let alone to designate a fairy-tale genre.

I am bound to conclude that Bottigheimer's distinction between rise and restoration tales is her own invention, one that unfortunately does not befit the nature of fairy tales. Interestingly, in a recent article Bottigheimer gives up on this ill-fated distinction while reverting to her first pronouncement on the matter. Across a twelveyear span, her basic view has been that fairy tales are "quintessentially" rise stories in which heroes and heroines "achieve elevation":

Culminating in a poor lass's or lad's brilliant wedding to a prince or princess, the modern fairy tale is quintessentially the story of a poor heroine who is crowned queen or ragged hero who takes up the scepter. (1994:282)

Fairy tales can be defined as complex narratives in which magic brings about closure and in which heros $[s i c]$ and heroines achieve elevation through a wedding in which one or both of the participants is royal. (2006:220)

Having clarified why I think that the rise/restoration distinction is specious, let me explain why I maintain that it entangles Bottigheimer's fairy-tale-invention argument. Since Bottigheimer equates Straparola's "previously undocumented tales" with fairy tales generally as well as with rise tales specifically (Bottigheimer 2002:2; cf. 1994:284-6, 290), she keeps two arguments going at once. The first one is restrictive: Straparola's contribution was the invention of "rise tales" (2002:2). In this strand of her thinking, Straparola's rise tales "marked the beginning of all modern fairy tales that reassured their readers that even the most miserably poor boy or girl could gain enormous material wealth" (6). Bottigheimer's second line of argument, however, is more encompassing: Straparola's "magic tales," which comprise restoration and rise tales, have "ultimately nourished Europe's hungry folk imagination" (2005:25-7). 
This fuzziness complicates the task of proving or disproving Bottigheimer's thesis. While she is ultimately claiming that Straparola initiated all modern fairy tales, she also restricts the issue to whether or not Straparola invented "rise" tales in order to minimize the burden of proof that her overall hypothesis has to sustain.

\section{The Proof}

And so we come to the matter of substantiation. The assertion that thirteen or so magic tales first published in Venice between 1551 and 1553 started the European fairy-tale tradition incurs a formidable burden of proof. To demonstrate this would require nothing short of magic, for it entails (1) being able to maintain that no "fairy tales that resemble modern ones" (Bottigheimer 1994:284) were in circulation before Straparola's Le piacevoli notti and (2) being prepared to show conclusively that Straparola's "invention" could have yielded the whole modern oral fairy-tale tradition, by literary means only, in just two and a half centuries. This section will investigate both claims.

\section{Fairy Tales before Straparola}

Because of Bottigheimer's definitions of "rise" and "restoration" tales, and her ambivalent suggestion that although Straparola invented all modern fairy tales he really only created "rise" tales, Bottigheimer can always state that any wonder tale preexisting Straparola's lifespan is not truly a "rise" tale. At this point, however, I feel free to move beyond these tangled definitions and to assume that the distinction between "rise" and "restoration" plots is irrelevant to the task of identifying fairy tales. From a folkloristic standpoint, the issue of whether modern fairy tales were documented before Straparola boils down to the question of whether tales belonging to ATU 300-749 and drawing on Propp's morphological scheme were recorded before Straparola.

I will deliberately start with a well-known example. The Latin writer Lucius Apuleius recorded the story of "Cupid and Psyche" as part of a larger novel, The Golden Ass, in the third century CE. In the framing narrative, the tale of "Cupid and Psyche" gushes from the mouth of an old woman who sets out to tell "the pretty story of an old wife's tale" (Apuleius 1999:74). Hence, it is presented as an oral tale. This is significant because its plot is similar to that of the modern international tale classified as ATU 425B ("Son of the Witch"). Jan-Öhjvind Swahn, in his study of this tale type, concludes that Apuleius "goes directly to contemporary folk-tradition, although with mythological additions" (1955:376). ${ }^{11}$ For his part, Stith Thompson makes the point that the version set forth by Apuleius cannot be considered the source of the modern European versions but that it rather "belongs to a widely diffused tradition which has considerable variation from place to place" ([1946] 1977:97). And William Hansen, in his fine survey of folklore themes in classical literature, notes that Apuleius's version "hints of a more traditional version in which the husband has the form of a snake or dragon by day," but it replaces the enchanted snake of the oral tale with a god, Eros, and casts the heroine as Psyche, so as to play allegorically with Platonic philosophy (2002:111). However this may be, we can in any case see that noted specialists who are familiar 
with traditional materials converge in their assessment of the tale's source-they all identify Apuleius's version as the literary adaptation of an ancient oral tale that shares basic traits with modern variants.

In direct contrast to this consensus, Bottigheimer simply applies to Apuleius's story her belief that every fairy tale must have a literary origin. She declares that "Cupid and Psyche' in its present form appears to be Apuleius's own invention" (1989:5). If Bottigheimer is right about this, then, of course, Straparola could hardly have invented this fairy tale. And the likelihood that she is wrong regarding Apuleius's authorship does nothing to improve Straparola's case, for he did not present a version of ATU 425 in his meager collection of fairy tales. The bottom line is that this fairy tale made it into a manuscript long before Straparola's lifetime.

Bottigheimer would presumably dismiss this example on the grounds that, since the heroine is a king's daughter, it is not a rise tale. However, it would also be impossible for Bottigheimer to define "Cupid and Psyche" as a restoration tale. Although the bride does start above rags, she also eventually rises beyond riches, for the princess Psyche-being a lowly mortal-is no proper match for the god whom she will marry in the end. Jupiter himself acknowledges the mismatch to the bridegroom's mother, even as he prepares to condone the marriage: "Have no fear for your high lineage and distinction in this marriage to a mortal, for I shall declare the union lawful and in keeping with the civil law, and not one between persons of differing social status" (Apuleius 1999:113). Thus, the bride has to rise (both literally and figuratively) in order to marry. After she ascends to heaven, Jupiter grants her immortality, and only then does the marriage ceremony take place. If we were to adopt Bottigheimer's schema, then we could say that in this story the rise pattern was in place (in a manner suitable to a literary variant featuring gods) many centuries before Straparola. However, this interpretation would disregard the typical fall-and-rise pattern of fairy tales. In accordance with this pattern, the heroine of the tale of "Cupid and Psyche" is first betrothed to a monster, and her sad marriage procession resembles the procession of her burial; indeed, Psyche then enters a netherworld phase in which she lays the foundation for the culminating marriage, not to a monster but to a god, a ceremony that will admit her to unprecedented heights. This complex fairy-tale pattern is irreducible to the "rise" or "restoration" dichotomy that Bottigheimer would force upon fairy tales.

A second example of a pre-Straparola fairy tale is ATU 314 ("Goldener"). It has been collected in modern oral versions featuring, alternatively, a well-born hero (Cosquin [1886] 1978, tale no. 12) or a dirt-poor one (Sébillot 2000:91-125; Delarue 1985:242-6). No matter what his initial status may be, the hero goes through a demeaning period of anonymity before he rises to fame. He works in a king's court as a lowly servant-often, one who barely speaks and who eats together with the dogs-but the princess eventually recognizes his worth and manages to marry him. The plot of ATU 314 was put into writing under several genres, in various languages, and at many different times throughout the Middle Ages (Delarue 1985:261; Micha 1996:19). A famous twelfth-century French manuscript, titled Robert le Diable (Robert the Devil), distinctly conveys the fairy-tale plot-although, as might be expected, the story appears laced with abundant courtly and pious references that are relevant to medieval audiences (much as Apuleius's story is laden with references that are pertinent to late-antiquity readers). In this literary 
version, as in Apuleius's story and in the literary "Cinderella" versions, the rise pattern happens one notch up in the social scale. The hero is the son of a duke, and by the end of the story he is offered the emperor's daughter along with the emperor's title. Further, the cultural context being medieval Christendom, this pious literary version expresses an ultimate rise in terms of the Christian paradigm of ascension: at the story's end, the hero forsakes marriage and chooses instead to enter the kingdom of heaven. The plot of ATU 314 could thus be construed as a rise tale if we disregarded the enchantmentlike trials and tribulations the hero has to undergo throughout the story. Again, this pattern of a fall followed by a supreme rise belies the possibility of distinguishing between "rise" and "restoration" plots. And again, the bottom line is that this fairy-tale plot made it into manuscripts long before Straparola's time, and Straparola did not include a version of this story in Le piacevoli notti. ${ }^{12}$

More examples could be provided, but this discussion should be adequate to establish that fairy-tale plots had been put into writing long before Straparola and that these plots thrived in modern oral traditions quite independently from Straparola's contribution. This brings us to the question of how exactly Straparola's thirteen or so magic tales might have spawned the European fairy-tale tradition.

\section{Straparola, Contes de Fées, and Oral Tradition}

According to Bottigheimer, Straparola's tales launched the literary creation and diffusion of European fairy tales by means of the French contes de fées: "Through the lengthy literary tales of Mme d'Aulnoy and her literary acquaintances, Straparolean magical motifs entered the arena of late seventeenth- and early eighteenth-century French contes de fees. The French literary efflorescence that followed spread Straparola's stories along with their magical motifs into France, England, and Germany" (2002:129). In a subsequent article, Bottigheimer (2005) develops this proposition by venturing that (1) there were no fairy tales in France before Straparola's stories entered this country via the book trade; (2) seventeenth-century French authors such as Charles Perrault and Catherine d'Aulnoy relied on Straparola's collection as they wrote their tales, and this initiated the French fairy-tale tradition; and (3) French fairy tales became part of an international book trade that carried forth Straparola's plots to nourish Europe's hungry folk imagination. All three assertions are untenable.

Regarding the first assertion, there is ample evidence of pre-seventeenth-century fairy tales in France. For example, the twelfth-century author Marie de France recorded a number of old stories out of which, she says, Breton lays (versified stories to be sung accompanied by the harp) were spun (Harf-Lancner 1990:12-3). Among the stories that Marie de France retells, Paul Delarue (1985:14) pinpointed ATU 400 ("The Man on a Quest for his Lost Wife"), ATU 432 ("The Prince as Bird"), and ATU 612 (“The Three Snake Leaves"). Delarue (1985:11) also notes that a collection of exempla named Scala Coeli, collected by a Dominican monk in the early fourteenth century, displays French versions of ATU 505 ("The Grateful Dead"), ATU 551 ("Water of Life"), ATU 671 (“The Three Languages"), and ATU 706 (“The Maiden Without Hands"). The international index further adds ATU 470A (“The Offended Skull”) to the list of fairy tales present in Scala Coeli (Uther 2004:276; cf. 305, 367).

Keep in mind that the issue at hand is Bottigheimer's claim that Straparola's "res- 
toration and rise tales" became "France's first fairy tales" (2005:26-7). In other words, the issue is whether French oral tradition included "rise" and "restoration" tales before the nineteenth century. While the above list suggests that it did, I wish to move beyond the display of tale titles and show how tricky the denial of "any folk knowledge of fairy tales before the nineteenth century" (Bottigheimer 2006:217) can be. Let us start with an interesting remark that Bottigheimer places under the heading of "Future Research" near the end of her 2005 article: "The bibliothèque bleue [a string of popular French chapbooks published between the seventeenth and nineteenth centuries] made use of 'Donkeyskin,' one tale type that Straparola included, but Straparola's story differed greatly from those versions. What can we learn about the routes of transmission of other versions of 'Donkeyskin' tales?" (2005:26). Unfortunately, Bottigheimer is not in a position to answer this question because the differences between Straparola's "Doralice" (night 1, story 4) and eighteenth-century French versions of ATU 510B ("Peau d'Asne") preexist any literary routes of transmission. Indeed, Bottigheimer fails to acknowledge some basic facts that should not go ignored.

First, Straparola's "Doralice" is not, strictly speaking, a "Donkeyskin" tale. It is instead an early example of ATU 510B* ("The Princess in the Chest"), in which there are no animal skins and the heroine does not work as a kitchen maid or as a poultry keeper. Charles Perrault's version of "Peau d'Asne," on the other hand, describes a heroine who hides in a skin and works as a lowly wench in the prince's palace. Second, Perrault's tale testifies to a French oral tradition of "Donkeyskin" that is quite independent from Straparola's contribution. For example, in his 1547 Propos rustiques (Rustic chatter), the French author Nöel du Fail mentions "Cuir d'Asnette" (lit., she-donkey's hide) among the tales being told in the veilée (evening gathering) of a Breton peasant household (du Fail [1547] 1921:69). Bottigheimer objects: "du Fail did not give the plot of the story told that night, so we do not know if it bears any resemblance to Perrault's tale" (2005:19). However, the fact that in modern Breton tradition variants of ATU $510 \mathrm{~B}$ are given the title "Peau d'Anette" suggests that, likewise, the "Cuir d'Asnette" story mentioned by du Fail was a "Donkeyskin" tale (see Delarue 1985:19 n. 21).

Bottigheimer also objects that "stories referred to as 'Peau d'Ane' embraced many different plots, such as Bonaventure des Perier's [sic] 1570 tale about a king who made his daughter wear a donkey skin to alienate her suitors. This was not a tale of magic but one of parental harassment" (2005:19). However, surely there must be at least a trifle of magic in a tale about a heroine who marries with the help of ants (see Cox 1893, tale no. 234). Likewise, Cinderella, in the Grimms' version of that story, enlists the aid of birds for a similar purpose. Indeed, the whole so-called Cinderella cycle, in which "Donkeyskin" is included (Rooth [1951] 1980; cf. Cox 1893; Hartland 1886), is about parental harassment: the heroine is persecuted by an evil stepmother or mother in ATU 510A ("Cinderella") and in ATU 511 ("One-Eye, Two-Eyes, Three-Eyes"); alternatively, she is harassed by a loving father in ATU 510B ("Peau d'Asne") or by a spiteful father in ATU 923 ("Love Like Salt") (see Dundes 1982:232-5; Vaz da Silva 2002:200-3). Long ago, Laurence Harf pointed out that the quaintness of des Périers's version of the tale arises from its synthesis of the "Cinderella" and "Donkeyskin" themes (1980:39), and this insight is crucial in regard to the understanding of the two themes as part of the closely-knit Cinderella cycle. Within this cycle, as Christine Goldberg 
notes, "however the tales are defined, there will inevitably be some variants that have characteristics of two or more types" (1997:28). The text presented by des Périers is arguably an extreme example of such fuzziness of type boundaries within the Cinderella cycle; still, it must count as evidence that the interrelated "Donkeyskin" and "Cinderella" themes were already known in France by Straparola's time.

We can also consider Jean de La Fontaine's fable 8.4, "Le pouvoir des fables" (The power of fables). In this fable about fables, the poet makes his case for the allegorical benefits of such tales, and he adds, "If someone was to tell me Peau d'âne, I would much rejoice. The world is old, they say, and I believe it; still, one must amuse it yet like a child" (La Fontaine 2002:239, my translation). This reference to "Donkeyskin," in a work first published in 1678, cannot possibly allude to Perrault's tale, which was published in 1694. Moreover, La Fontaine's specific choice of "Donkeyskin" as an example of a tale he would hear with profit - and as a paradigm of tales that amuse children as well as the grown-up denizens of an old world-indicates that this fairy tale was well known in oral tradition.

More evidence is provided by an anonymous contemporary critic, who grieved that Perrault did not shed some of his intellect on the tale in 1694 instead of simply replicating it as it was babbled throughout centuries by a host of imbecilic nannies and young children (Soriano 1977:113-4). This critic's point is that Perrault was faithfultoo faithful, he complains - to the way dimwitted people had fashioned the tale for a long time, a complaint that plainly indicates the existence of an oral tradition. ${ }^{13}$ Furthermore, the following year (in his 1695 preface to the fourth edition of Grisélidis), Perrault remarked that Apuleius's tale of Psyche is "an old woman's tale like that of Donkeyskin," which-he specifies- "is told daily to children by their governesses and grandmothers" (Perrault 1989:181-2, my translation; cf. Delarue 1954:252). Perrault also quotes a comment that his niece, Mlle. Lhéritier, a fairy-tale writer in her own right, appended to the "Donkeyskin" tale that he sent to her. Says Lhéritier, "the tale of Donkeyskin is here retold with such naïveté that it amused me no less than when my nurse or my maidservant, telling it by the fireplace, held my mind spellbound" (Perrault 1989:184, my translation).

Despite all of this, Bottigheimer maintains that the words chosen by Perrault to discuss fairy tales exclude any use of oral sources and confirm the use of literary materials (2007b:150). Given this drastically selective mode of interpretation, the French oral tradition of "Donkeyskin" cannot but be flatly denied. Bottigheimer asserts that "Perrault used Basile's and Straparola's tales as a model, as a template, for the donkeyskin tale he was in the process of composing," and that Perrault's tale was an "instance of recycling already existing old Italian tales as new French ones" (2006:215). Bottigheimer even imagines Perrault at work in his office with Basile's and Straparola's books open before him, creating his story as a composite from these sources-and not from oral tradition, this very notion being "erroneous" (2007b:151, 157). Hence, she declares that "all motifs in Perrault's tale come from the tales of Basile and Straparola" (2007b:152). All motifs? The central "Donkeyskin" motif of Perrault's story was not present in either Basile's or Straparola's tales. But Bottigheimer has a solution for this. Ever keen to dismiss any hint of oral tradition, she fancies Perrault as taking his literary hint from des Périers or even from Apuleius-as long as it is from a book. 
The better to allay the suspicion that the "Donkeyskin" motif was a staple of French oral tradition, Bottigheimer argues that Perrault's title was surely a plaisanterie littéraire (literary joke) (2007b:151). As she puts it, Perrault named the story "Peau d'Ane" because "in his day, fanciful or nonsense tales were called contes de peau d'asne, donkeyskin tales, and so when he wrote a tale about a donkeyskin, he was composing a donkeyskin tale" (2006:215). Leaving aside the truism that Perrault was composing a donkey skin tale when he wrote about a donkey skin, the interesting thing to note here is that Bottigheimer ends up reinstating the very notion that she tries to exorcise. To assume that Perrault was slyly alluding to "fanciful or nonsense tales" as contes de peau d'âne implies acknowledging that the "Donkeyskin" tale was popular enough in his time that it could stand for the whole spectrum of "fanciful" tales. Hence, Bottigheimer unwittingly mirrors La Fontaine's citation of "Peau d'Ane" to metonymically evoke oral tales fit to amuse children and grown-ups alike. She is also in tune with Delarue, who confirms that the expression "donkeyskin tale" was used to designate fairy tales even before Perrault's time: “The tale of 'Donkeyskin' was so well known that, for a very long time, the term conte de peau-d'âne had been synonymous with conte de ma mère l'Oye, with conte bleu, with conte d'ogre et de fée, and a lexicographer would easily find some fifteen phrases containing the expression conte de peau-d'âne in works preceding the publication of Perrault's versified tale" (Delarue 1954:252-3, my translation). It therefore stands to reason that when Perrault used the title of "Donkeyskin" for a tale that hinges on a donkey skin, he was simply calling by its correct name, in the context of French tradition, the familiar ATU 510B plot, which he was writing down for the literary delight of future generations.

Regarding another of Perrault's stories, Bottigheimer claims that the tale of "Le chat botté" was also derived from Straparola. This statement misrepresents the matter. The oral tradition of ATU 545B ("Puss in Boots") is extant throughout the Indo-European world and as far away as Siberia, as well as in many extra-Eurasian locales. This widespread oral tradition often presents the animal helper as a fox rather than a cat; in this and other aspects, the various renditions of the tale are quite independent from the Italian and French literary versions (Delarue and Tenèze 1977:345-6). A Norwegian tale called "Lord Peter," for example, presents in a characteristic fairy-tale manner the castle that the hero of the story is to appropriate. This otherworldly castle is so dazzlingly white that it hurts one's eyes to look at the sunlight glittering on it. It belongs to a troll, and the helpful puss in boots tricks this troll into being destroyed by staring at the sun (Asbjørnsen and Moe 1888). Confirming the importance of this traditional motif, a Sicilian tale says that the magnificent castle belongs to a couple of ogres, whom the fox convinces to hide inside the oven before setting it ablaze (Gonzenbach [1870] 1989:284-90; cf. Calvino 1982:661-6). In the same vein, the tale representing ATU 545 in the French catalogue has the fox convince all the inhabitants of the castle to hide in haystacks, which he then lights on fire. Marie-Louise Tenèze remarks that this motif recurs outside of France in spots far enough apart that we may assume an ancient tradition (Delarue and Tenèze 1977:339-42; Delarue [1956] 1980, tale no. 13). ${ }^{14}$ Surely, this tradition exists independently of Straparola, whose version lacks both the otherworldly castle and the troll/ogre/giant/dragon as owner. On the other hand, Perrault does present the castle's owner as a prodigiously rich ogre, which suggests that Delarue is right when he states that Perrault drew on oral materials (Delarue 1951a:200; cf. 
Soriano 1977:171). ${ }^{15}$ The main point is that, whatever the influence of Straparola's and Basile's texts on Perrault's "Le chat botté," all three literary versions are but an offshoot of a richer tradition that can hardly be retraced to them (see Delarue and Tenèze 1977:345-6). To say otherwise would require detailed proof by way of literary history, which so far Bottigheimer has not produced.

Now let us turn to Bottigheimer's assertion that seventeenth-century French authors relied on Straparola's collection as they wrote their tales, which then supposedly initiated the French fairy-tale tradition. For instance, Bottigheimer asserts that the fairy-tale author Mme de Murat "spoke the truth" in claiming that everybody, including herself, was taking their stories from Straparola (Bottigheimer 2005:23-4; see also 2002:128-9). But, surely, the point is to assess, beyond easy generalizations, what Straparola's presence in French tales amounts to. In Fairy Godfather, Bottigheimer asserts that six of the tales by a major French writer, Mme d'Aulnoy, are derived from Straparola (2002:129). Subsequently, and more soberly, she draws attention to the likelihood that d'Aulnoy's "La princesse Belle-Etoile" (The princess beautiful star) follows Straparola's third story of the fourth night - and she hints that this might be a wider phenomenon (2005:17-8). Bottigheimer fails to acknowledge Delarue's conclusion that d'Aulnoy took exactly three tales from Straparola and used at least twice that many from oral tradition (Delarue 1985:20-1). Further, while none of Perrault's stories have been conclusively traced back to Straparola (pace Bottigheimer's claims concerning "Peau d'Ane"), the vast majority of them remain extant in modern folk tradition (Delarue 1951a:197). In marked contrast, while Mme de Murat may have borrowed from Straparola, Delarue notes that none of her stories are present in the modern oral tradition (Delarue 1985:21). This seems to provide still more evidence that Straparola cannot account for most seventeenth- and eighteenth-century French tales that have matches in oral tradition. Nor does Bottigheimer present any evidence to the contrary. To show that Straparola's Le piacevoli notti was available and successful in France between 1560 and 1615, which she did convincingly in her 2005 article, does not amount to demonstrating that the subsequent French output of literary fairy tales was built on Straparola's work-or that this output spawned the French oral tradition.

\section{Straparola and Modern Fairy-Tale Tradition}

Bottigheimer claims that the seventeenth-century contes de fées carried Straparola's tales into a literary chain that would eventually spawn the European oral tradition. However, she did not (and, I emphasize, could not) demonstrate this claim. A couple of examples will suffice to drive this point home. First, consider Straparola's tale of "Fortunio" (night 3, story 4). Bottigheimer variously presents this story as a "rise" tale (2005:25), as a "restoration" tale (2002:91), and as a rise tale with a restoration tale appended to it (2002:22). However, even a cursory glance at the tale-type index shows that this supposedly dual story is but one stable plot classified as ATU 316 ("The Nix of the Mill-Pond"). This story is best known from the Grimms' collection, where a note informs us that the story is "current in Upper Lusatia" (Hunt [1884] 1968, vol. $2: 460$ ). Indeed, the diffusion area of this tale is mainly northern Europe (Delarue 1985:274; Thompson [1946] 1977:58).

Several remarkable versions of ATU 316 have been collected in Gaelic from Scot- 
land in the 1850s and then translated into English and published by J. F. Campbell ([1860-1861] 1994, vol. 1:147-72). Campbell was aware that the same story had been published in George W. Dasent's collection of Norse tales (1859) as well as in the Grimms' collection, but he plausibly ruled out literary transmission in both instances. He wavered regarding the origin of this tale, though. Campbell believed that his collected texts, brimming with Celtic motifs, must express "the Gaelic version of some old myth"-indeed, "a very old tale" ([1860-1861] 1994, vol. 1:172). But one of the helpful animals that appears in the tale is a lion, and this incongruous detail gives Campbell reason for admitting that he "cannot say how the story got to the Highlands." However this may be, it is certain that the lion did not come from Straparola's text, which features a more homely wolf. Nor could most of the other specific traits of Campbell's texts have originated in Straparola's story, which shares few of the details of the Scottish variants.

The Scottish stories are also far more precise in both their framework and their details, in comparison to the lapses and ambiguities of Straparola's version; this fact makes it implausible that the former are derived from the latter. Straparola's hero is the adopted son of a childless couple, who, for no apparent reason, manage to have a child of their own later in the story. Further, Fortunio's misfortunes with a siren have their cause in a rather unmotivated curse his adoptive mother puts on him. On a strikingly different note, the Scottish variants explain both features in a coherent framework: it is because the siren had bestowed children and abundance on the barren couple, in exchange for the first child to be born, that the child must go to her afterward: "It is a long time since you were promised to me, and now I must have thee perforce," says the siren in one Scottish variant (Campbell [1860-1861] 1994, vol. 1:170). This comparative fact suggests that Fortunio, the found child, is really the siren's token. Straparola's text obscures this underlying rationale, which Scottish tradition preserves.

Similarly, it is not clear why in Straparola's version Fortunio must compete in a three-day nuptial tournament to save the king's beloved daughter from bondage to a hideous Saracen; nor is it clear why, having killed the Saracen on the first joust, he must then fight on for two more days. The Scottish variants show that the hero progressively rescues the princess from a three-headed sea dragon (or giant) by slicing off one head per day-thus winning the princess after three days. Again, Straparola's text obscures this underlying rationale of a triple fight against a three-headed monster, which the northern variants preserve.

In order to make a credible case that Straparola invented this tale, Bottigheimer would have to show specific literary links taking Straparola's text into the vernacular traditions of Scandinavia and Gaelic-speaking Scotland and Ireland. Moreover, she would have to explain how this northern tradition has evolved locally in ways that clarify details left obscure in the original Italian text. Until such unenviable tasks are completed, the fact that the Scottish variants can clarify details that remain obscure in Straparola's text (which, in turn, adds nothing to the understanding of the northern tales) suggests that Straparola's version is a derivate text within the pan-European tradition, not its primary source.

My second example concerns Straparola’s "Cesarino" (night 10, story 3). Even 
though this story is about a poor lad who marries a princess by magical means, Bottigheimer does not mention it in her otherwise detailed discussion of "rise" tales (2002:18-27). She also fails to mention this story in her discussion of fairy tales appearing in the second volume of Straparola's Le piacevoli notti (111-2). In fact, Bottigheimer's silence on this tale is deafening. All she says about "Cesarino" is that it is analogous to Basile's "The Merchant's Two Sons" (2002:2) and that it "charmed none of France's storytellers" (2005:25). The acknowledgment that "Cesarino" did not appeal to France's literate storytellers is most instructive. This tale is an instance of ATU 300 ("The Dragon Slayer"), which is arguably a core plot in the European store of magic tales. Antti Aarne placed it at the head of all magic tales, and Propp saw it as the generative prototype of all fairy tales. In fact, this tale registers all across the Indo-European landscape in different regional versions, none of which bears the mark of Straparola's version. The evidence suggests that this tale emerges from a very old tradition (see Thompson [1946] 1977:29-32). In this context, Bottigheimer's acknowledgment that French literary storytellers did not take to Straparola's text is decisive. It entails recognizing that the complex tradition of ATU 300, which extends throughout the Indo-European landscape and beyond, could not derive from Straparola's version by means of French literary channels. All by itself, this example disproves Bottigheimer's claim that French literary fairy tales carried on Straparola's plots to nourish Europe's hungry folk imagination.

\section{Conclusion}

It is time to step back and look at the big picture. I have argued that rise tales turn out to be Bottigheimer's own invention and that the proposition that Straparola invented rise tales relies on fuzzy logic and disregards existing data. I also pointed out that a wonder-tale template underpins Bottigheimer's invention of Straparola's life and wondrous deed. It is a distinctive property of wonder tales to redefine their own world beyond principles of strict rationality and to develop their inner logic with scant reference to empirical reality. In this sense, I have suggested that Bottigheimer's construction is her own wonder tale of sorts.

This said, I acknowledge that Bottigheimer's argument is a welcome challenge to folklorists who would persist in disregarding literary texts as a matter of principle. Her vigorous prose issues a wake-up call and insists that we should fully recognize the longstanding interplay between literary texts and oral materials in literate societies. In this sense, Bottigheimer's argument can foster a greater awareness of the complexity of fairy tales. Whether Bottigheimer herself will eventually engage with studies in oral tradition and move beyond the old literary/oral dichotomy is quite another matter. But optimism is one defining characteristic of wonder tales, and scholars in this realm have beheld greater wonders.

\section{Appendix: How Many Fairy Tales Did Straparola "Invent"?}

When Bottigheimer mentions "previously undocumented tales" invented by Straparola in Le piacevoli notti (2002:2), to which of the tales in particular does she refer? The answer is not straightforward. In a 
1994 article she mentions "fifteen tales in Straparola's collection for which no previous analog exists," which are "Straparola's magic tales, tales that seem to be his own invention, Straparola's legacy to the Western world" (285). However, in Fairy Godfather she mentions only thirteen of Straparola's stories that "folk narrativists have come to identify ... as fairy tales" (2002:1). In a subsequent article, she likewise describes thirteen "magic tales" in Straparola's collection (2005:25); however, it turns out that this list has only nine stories in common with the thirteen stories discussed in Fairy Godfather (see Table 1).

Moreover, if we compare the 2005 list of tales with Bottigheimer's 2002 comments in Fairy Godfather, we learn that only five stories are unequivocally deemed "rise" tales and explicitly branded as Straparola's creations: "The Prince Pig" (night 2, story 1), "Peter the Fool" (night 3, story1), "Adamantina and the Doll” (night 5, story 2), "The Tailor's Apprentice” (night 8, story 5), and "Costantino and His Cat" (night 11, story 1). Six other tales, deemed "restoration" tales and not described as Straparola's inventions, are "Doralice" (night 1, story 4), "Livoretto" (night 3 story 2), "Biancabella” (night 3, story 3), "Costanza/ Costanzo" (night 4, story 1), "Ancilotto" (night 4, story 3), and "Guerrino" (night 4, story 5). Finally, two tales have dubious categorizations: "Fortunio" (night 3, story 4) is said to be part "rise" and part "restoration." "Cesarino" (night 10, story 3 ) is not explicitly placed in either category, for Bottigheimer says virtually nothing about it, apart from noting that it is a magical tale. (However, since "Cesarino" is a rise tale by Bottigheimer's standard, I count her rise tales at six in this article.)

Table 1. Categorization of Straparola's tales in two of Bottigheimer's works (strikethrough text indicates factual errors).

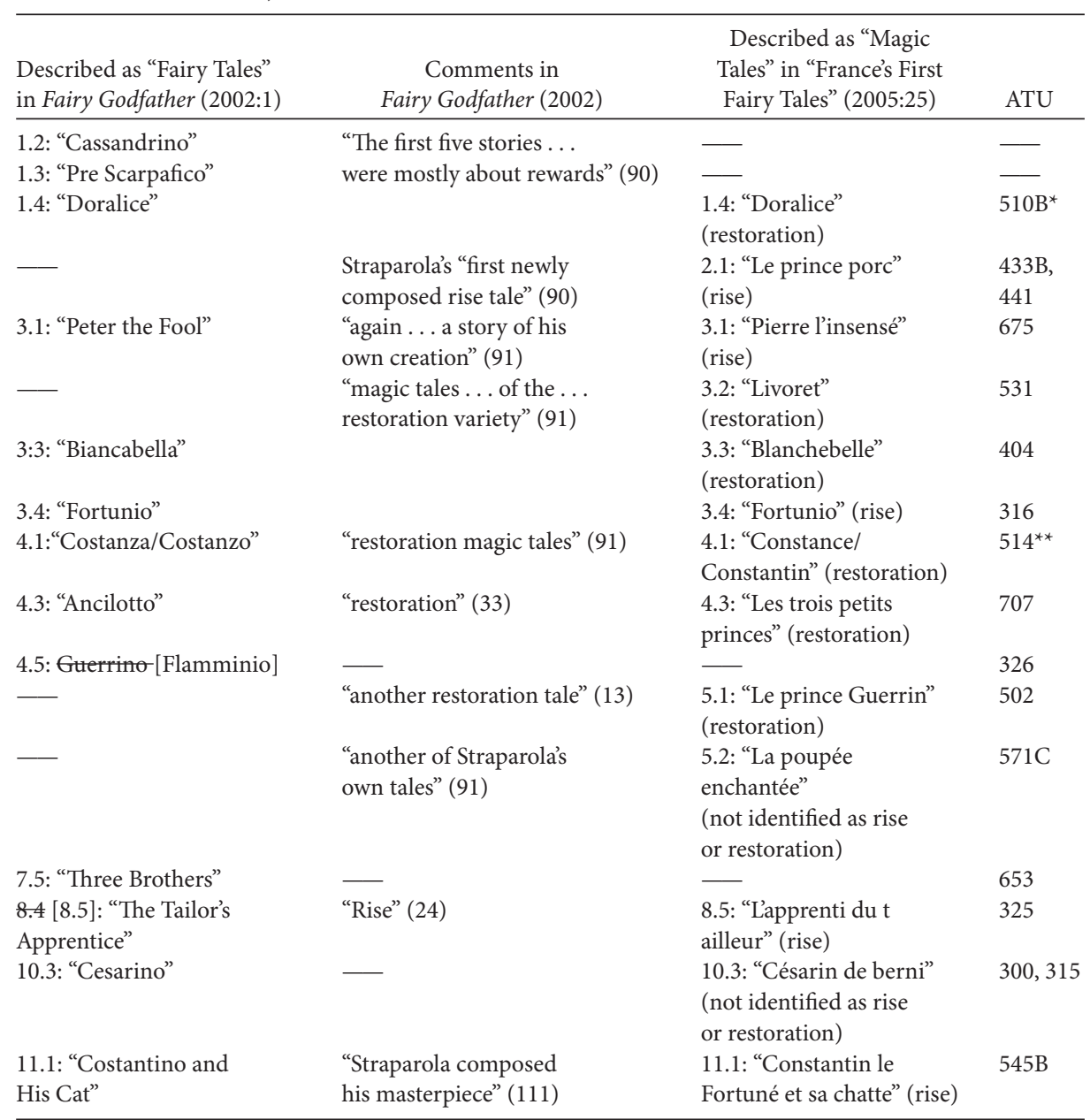


In short, Bottigheimer's 1994 account states that there are fifteen magic stories in Le piacevoli notti "for which no previous analogue exists" (1994:285); these are deemed Straparola's invention and legacy. Fairy Godfather mentions thirteen "fairy tales" in Le piacevoli notti (2002:1), but here, the "previously undocumented tales" that Straparola purportedly invented are said to be "rise tales" (2002:2), of which only five examples are unequivocally recognized. And yet her 2005 article considers a group of thirteen (“Straparola's restoration and rise tales") as "France's first fairy tales," which "ultimately nourished Europe's hungry folk imagination” (2005:25-7).

\section{Notes}

While writing this article, I incurred a scholarly debt that I cherish. With admirable equanimity, Ruth B. Bottigheimer provided me with copies of several of her articles and made detailed comments on a previous version of this critique. She allowed me to review a late draft of her "Fairy Godfather, Fairy-Tale History, and Fairy-Tale Scholarship" (published in this issue), in light of which I have clarified some aspects of my own argument. I thank Bottigheimer for her graciousness and patience during our lengthy e-mail exchanges. I also wish to thank Jesse L. Rester and the rest of the editorial team of the Journal of American Folklore for their diligent work in copyediting this article.

1. Bottigheimer grants herself this biographical license after the precedent of Paul Larivaille, who recognizes Straparola's childhood and adolescent biography in the tale of "Costantino Fortunato" (night 11, story 1). Bottigheimer, while approving of this "psychocritical" approach, feels free to change the source tale (2002:52). Thus used, the "psychocritical" approach allows for arbitrary choices among the tales in Le piacevoli notti to spawn different renderings of the unknown life of Straparola. While such choices may say something about their authors, they are bound to leave the life of Straparola as obscure as ever.

2. Bottigheimer acknowledges that "between roughly 1890 to $1910 \ldots$ vigorous debates took place among oralists and non-oralists, and without exception the oralists beat back the non-oralists." But she would dissociate Wesselski from this verdict: "Against a strong tide in the opposite direction, Albert Wesselski argued in the 1920s and 1930s in favor of a book history for the dissemination of fairy tales. Nazi-led Germany, however, was inhospitable to non-folk-valorizing and hence heretical ideas. Wesselski's theories were dismissively ridiculed for the next seventy years" (2006:220; cf. 2007c:12). But Nazism did not last for seventy years, and this explanation ignores the epic dispute that raged between Wesselski and Walter Anderson, the German folklorist from the University of Tartu (for an overview of the issues at stake, see Kiefer [1947] 1973). Moreover, the support that Stith Thompson (1937), one of the founding fathers of American folkloristics, granted to Anderson against Wesselski's ideas would suffice to show that Wesselski's lack of influence in the history of folkloristics cannot be ascribed to the effect of National-Socialist ideology on the field. It is arguable, however, that echoes of Wesselski's position endure in German scholarship up to the present day as a longstanding reaction to the exploitation of romantic folk theories in the Third Reich (see Ward 1994:10-2).

3. Bottigheimer actually uses this expression in reference to the "literate subworld" of Venice, the "hunger" of which has a slightly different meaning than that of the illiterate folk: "Straparola provided newly conceptualized literary provender for a public hungry for promises of a better life" (2002:17).

4. In this assessment I am not taking into account Bottigheimer's inventive (if, alas, irrelevant) distinction between "rise" and "restoration" tales, which I address below. I am also excluding a handful of tales that, according to the tale-type index, had actually been documented before Straparola. (These include ATU 432, 433B, 513A, 533, 653, and 707.) The tales that I am counting-most of which were published either by Straparola himself or by Basile-are ATU 310, 316, 325, 326, 327A, 327B, 328, 333, 360, 361, $408,410,425 \mathrm{C}, 425 \mathrm{E}, 441,476,500,501,510 \mathrm{~A}, 510 \mathrm{~B}^{\star}, 516,531,545 \mathrm{~B}, 552,559,560,564,571,571 \mathrm{C}, 652$, 675,710 , and $740^{\star *}$. I do not claim that this listing is exactly accurate; its purpose is merely to suggest an approximate ratio between collected oral tales and inventoried literary versions.

5. A similar point has been made by other specialists in indigenous American traditions regarding wider swaths of traditional lore (beyond the context of fairy tales). For instance, apropos of blond fairies in the folklore of a number of indigenous groups from the Amazonian region, anthropologist Luis Eduardo Luna notes that "it is ... probable that New World inhabitants adopted and adapted the archaic 
Spanish religious terms and imagery because these paralleled existing indigenous beliefs." Likewise, Luna sees in traditions about mermaids "the persistence of indigenous beliefs under the cover of European terminology" (Luna and Amaringo 1991:36).

6. From another perspective, Donald Ward argues that literary variants in oral tradition can be readily identified. In his words, "the Print-Tales and Oral-Tales have not cojoined into a homogeneous mixture, as some folklorists have assumed. The domain (either that of print or that of orality) to which a given tale belongs is highly conspicuous within the confines of a given narrative tradition" (1994:28). Needless to say, the pertinent remark that one recognizes a literary tale when one hears it in the context of a given tradition precludes Bottigheimer's assumption that all oral tales are at the most three steps away from a book source.

7. In this sentence I am supplementing Bottigheimer's specific statement regarding "rise" plots with her subsequent, wider statement that it was both Straparola's "restoration and rise tales" that yielded "France's first fairy tales" and, thus, "ultimately nourished Europe's hungry folk imagination" (2005:26-7). Such broader contextualization is necessary given Bottigheimer's definitional haziness, which I discuss below.

8. It is also widely understood that some tale types presently placed within the ATU 300-749 range should probably have been classified elsewhere, and that some tales located elsewhere in the index ought to be brought into the "magic tales" section. Even so, the international index contains within the ATU 300-749 range most of the tales displaying Propp's morphology by means of an array of marvelous elements, which is what matters for the present discussion.

9. Incidentally, Bottigheimer's claims about Cinderella's wealthy background are not quite right. Granted, in literary tales Cinderella often starts out as the daughter of wealthy people. Orally collected tales, however, tend to present her as the daughter of poor people, or else they do not specify the family's social standing. Overall, what really matters is the girl's depreciated position within the family, and it seems that narrators are free to decide what the family's social and economical status is. For example, consider the first five "Cinderella" tales in Marian Roalfe Cox's compilation of variants (1893:1-3): two Finnish texts present the heroine and her sisters as farmers' daughters who become servants at the royal palace; two Italian versions describe the plight of a heroine ill-treated by her stepmother, with no reference to social standing; and one Scottish text declares that the heroine is a gentleman's daughter. Regardless of the heroine's original social standing, in all five cases her royal marriage entails rise. Hence, credit must be given to Bottigheimer's perception that "the heroine's restoration surpasses her original social and economic level" (2002:1); but then, one is also bound to acknowledge that Cinderella's socalled restoration actually involves a rise plot.

10. This can occur by a range of means, such as otherworldly trials and tribulations, underground imprisonment, concealment under soot or fur, or a dire period of maiming, blindness, or muteness (see Cardigos 1996:121-68; Vaz da Silva 2000).

11. As Swahn puts the matter, "the fact that Apuleius' tale only represents one of at least 15 special tradition forms ought to speak for itself." Moreover, he adds that Apuleius's version lacks a motif found in the majority of tradition areas and found in such separate areas as India/Indonesia and Scandinavia. This, he submits, is "irrefutable evidence that Apuleius' tale of Cupid and Psyche is only one variant among many" (1955:408).

12. Stith Thompson ([1946] 1977:182) says that Straparola presented a version of "Goldener," but he is wrong in this regard. Straparola did present, in the first story of the fifth night, an instance of the kin plot ATU 502 (“The Wild Man”). This plot is likewise documented since the thirteenth century (see Uther 2004:288), and so Straparola could not have invented it either.

13. Incidentally, the notion that this tale is coarse after being the possession of dimwitted people coincides with Ziolkowski's (2002:103) demonstration that throughout the centuries folk tales were associated with the illiterate and the poor, as well as with Apuleius's framing of the tale of "Eros and Psyche" as having been told by a raving, drunken old woman.

14. Moreover, ATU 545A ("The Cat Castle") — the kin plot featuring a heroine who is also helped by an animal that kills the troll/giant owner of the castle by making him look at the sun-occurs "mostly in northern Europe" (Uther 2004:315). It would be interesting to know by what literary twists Straparola's tale turned into these two plots (ATU 545A and 545B), each of which conveys a widespread tradition 
hinging on a supernatural motif that is lacking in Straparola's version. Bottigheimer remains conspicuously silent on this matter.

15. Furthermore, Basile's tale includes a final episode on the ingratitude of the lad toward the cat, which is often displayed in oral versions of the theme but is absent in Straparola's text. Straparola, for his part, includes in his version a striking episode in which the cat licks Costantino thoroughly in order to smooth and heal his botched skin. This episode is also probably drawn from oral tradition, and it is absent in both Perrault's and Basile's variants. In all likelihood, the three literary versions independently drew on regional oral traditions, which is why it is simply not enough to assess what the texts owe to each other.

\section{References Cited}

Apuleius. 1999. The Golden Ass, trans. P. G. Walsh. Oxford: Oxford University Press.

Asbjørnsen, Peter Christen, and Jørgen Engebretsen Moe. 1888. Popular Tales from the Norse. Trans. George Webbe Dasent. 3rd ed. Edinburgh: Douglass.

Bacchilega, Cristina. 1997. Postmodern Fairy Tales: Gender and Narrative Strategies. Philadelphia: University of Pennsylvania Press.

Bottigheimer, Ruth. 1989. Cupid and Psyche vs. Beauty and the Beast. Marvels and Tales 3(1):4-14.

- 1993. Luckless, Witless, and Filthy-Footed: A Sociocultural Study and Publishing History Analysis of “The Lazy Boy." Journal of American Folklore 106(421):259-84.

- 1994. Straparola's Piacevoli Notti: Rags-to-Riches Fairy Tales as Urban Creations. Marvels and Tales 8(2):281-96.

- 2002. Fairy Godfather: Straparola, Venice, and the Fairy Tale Tradition. Philadelphia: University of Pennsylvania Press.

. 2005. France's First Fairy Tales: The Restoration and Rise Narratives of Les Facetieuses Nuictz du Seigneur Francois Straparole. Marvels and Tales 19(1):17-31.

— 2006. Fairy Tale Origins, Fairy Tale Dissemination, and Folk Narrative Theory. Fabula 47(34):211-21.

. 2007a. Books, Folks, and Fairy Tales. ISFNR Newsletter 2:18-9.

- 2007b. Perrault au travail. In Le conte en ses paroles: La figuration de loralité dans le conte merveilleux du Classicisme aux Lumières, ed. Anne Defrance and Jean-François Perrin, pp. 150-9. Paris: Desjonquières.

—. 2007c. Preface. In "Fairy Tales, Printed Texts, and Oral Tellings", ed. Ruth Bottigheimer. Special issue, Marvels and Tales 21(1):11-5.

Calvino, Italo. 1982. Italian Folktales, trans. George Martin. 2nd ed. Harmondsworth: Penguin.

Campbell, J. F. [1860-1] 1994. Popular Tales of the West Highlands, Orally Collected. New ed. 2 vols. Edinburgh: Birlinn.

Cardigos, Isabel. 1996. In and Out of Enchantment: Blood Symbolism and Gender in Portuguese Fairytales. Helsinki: Academia Scientiarum Fennica.

Cosquin, Emmanuel. [1886] 1978. Contes populaires de Lorraine comparés avec les contes des autres provinces de France et des pays étrangers, et précédés d'un essai sur l'origine et la propagation des contes populaires européens. Vols. 1-2. Marseille: Lafitte Reprints.

Cox, Marian Roalfe. 1893. Cinderella: Three Hundred and Forty-Five Variants of Cinderella, Catskin, and Cap o' Rushes Abstracted and Tabulated with a Discussion of Mediaeval Analogues, and Notes. London: Nutt.

Dasent, George Webbe. 1859. Popular Tales from the Norse. Edinburgh: Edmonston and Douglas.

Dégh, Linda. [1969] 1989. Folktales and Society: Story-Telling in a Hungarian Peasant Community, trans. Emily M. Schossberger. Expanded ed. Bloomington: Indiana University Press.

- 1995. Narratives in Society: A Performer-Centered Study of Narration. Helsinki: Academia Scientiarum Fennica.

- 1996. Hungarian Folktales: The Art of Zsuzsanna Palkó, trans. Vera Kalm. Jackson: University Press of Mississippi. 
Delarue, Paul. 1951a. Les contes merveilleux de Perrault et la tradition populaire: Introduction. Bulletin folklorique d'Ile-de-France 13 (January-March):195-201.

_ 1951b. Les contes merveilleux de Perrault et la tradition populaire: "Le petit chaperon rouge" [Part 1]. Bulletin folklorique d'Ile-de-France 13 (April-June):221-8.

- 1951c. Les contes merveilleux de Perrault et la tradition populaire: "Le petit chaperon rouge" [Part 2]. Bulletin folklorique d'Ile-de-France 13 (July-October):251-60.

- 1951d. Les contes merveilleux de Perrault et la tradition populaire: "Le petit chaperon rouge" [Part 3]. Bulletin folklorique d'Ile-de-France 13 (October-December):283-91.

- 1953. Les contes merveilleux de Perrault et la tradition populaire: Compléments et rectifications aux articles précédents. Bulletin folklorique d'Ile-de-France 15 (July-September):511-7.

- 1954. Les contes merveilleux de Perrault: Faits et rapprochements nouveaux (suite). Arts et Traditions Populaires 2(3):251-74.

— Press.

-1985. Le conte populaire français: Catalogue raisonné des versions de France et des pays de langue française d'outre-mer. Vol. 1, 2nd ed. Paris: Maisonneuve et Larose.

Delarue, Paul, and Marie-Louise Tenèze. 1977. Le conte populaire français: Catalogue raisonné des versions de France et des pays de langue française d'outre-mer. Vol. 2. Paris: Maisonneuve et Larose.

du Fail, Noël. [1547] 1921. Propos rustiques, ed. Jacques Boulenger. Paris: Bossard.

Dundes, Alan. 1987. The Symbolic Equivalence of Allomotifs in the Rabbit-Herd (AT 570). In Parsing through Customs: Essays by a Freudian Folklorist, pp. 167-77. Madison: University of Wisconsin Press.

_ 1989. Interpreting "Little Red Riding Hood" Psychoanalytically. In Little Red Riding Hood: A Casebook, ed. Alan Dundes, pp. 192-236. Madison: University of Wisconsin Press.

Dundes, Alan, ed. 1982. Cinderella: A Folklore Casebook. Garland Folklore Casebooks 3. New York: Garland.

Foley, John Miles. 1988. The Theory of Oral Composition: History and Methodology. Bloomington: Indiana University Press.

Goldberg, Christine. 1997. The Donkey Skin Folktale Cycle (AT 510B). Journal of American Folklore 110(435):28-46.

Gonzenbach, Laura. [1870] 1989. Sizilianische Märchen. Nördlingen: Greno.

Goody, Jack. 1977. Mémoire et apprentissage dans les sociétés avec et sans écriture: La transmission du Bagre. L'Homme 17(1):29-52.

- 2002. The Telling of Tales in Oral Cultures. In Mediterranean Ethnological Summer School, ed. Bojan Baskar and Irena Weber, vol. 4, pp. 9-16. Ljubljana: Univerza v Ljbubljani, Filozofska fakulteta, Oddelek za etnologijo in kulturno antropologijo.

Hansen, William F. 2002. Ariadne's Thread: A Guide to International Tales Found in Classical Literature. Ithaca, NY: Cornell University Press.

Harf, Laurence. 1980. Le conte de Peau d’Ane dans la littérature du Moyen-Age et du XVIème siècle. Réforme Humanisme Renaissance 11(1):35-42.

Harf-Lancner, Laurence. 1990. Introduction. In Lais de Marie de France, by Marie de France, pp. 17-9. Paris: Le Livre de Poche.

Hartland, Edwin Sidney. 1886. The Outcast Child. Folk-Lore Journal 4(4):308-49.

Hélias, Pierre Jakez. 1990. Le quêteur de mémoire: Quarante ans de recherche sur les mythes et la civilisation bretonne. Paris: Plon.

Holbek, Bengt. [1987] 1998. Interpretation of Fairy Tales: Danish Folklore in a European Perspective. Helsinki: Academia Scientiarum Fennica.

Hunt, Margaret, trans. and ed. [1884] 1968. Grimm's Household Tales, with the Author's Notes. 2 vols. Detroit: Singing Tree Press.

Jakobson, Roman, and Petr Bogatyrev. [1929] 1982. Folklore as a Special Form of Creativity. In The Prague School: Selected Writings 1929-1946, trans. Manfred Jacobson, ed. Peter Steiner, pp. 32-46. Austin: University of Texas Press.

Kiefer, Emma Emily. [1947] 1973. Albert Wesselski and Recent Folktale Theories. New York: Haskell House. 
La Fontaine, Jean de. 2002. Fables, ed. Jean-Charles Darmon and Sabine Gruffat. Paris: Le Livre de Poche. Lévi-Strauss, Claude. 1991. Histoire de Lynx. Paris: Plon.

Lord, Albert B. 2000. The Singer of Tales, ed. Gregory Nagy. 2nd ed. Cambridge, MA: Harvard University Press.

Luna, Luis Eduardo, and Pablo Amaringo. 1991. Ayahuasca Visions: The Religious Iconography of a Peruvian Shaman. Berkeley, CA: North Atlantic Books.

Micha, Alexandre. 1996. Introduction to Robert le Diable: Roman du XIIe siècle. Paris: GF-Flammarion.

Mitchell, Stephen A. 1991. Gråkappan (AT 425) as Chapbook and Folktale in Sweden. In The Ballad and Oral Literature, ed. Joseph Harris, pp. 269-91. Cambridge, MA: Harvard University Press.

Perrault, Charles. 1989. Contes. Ed. Marc Soriano. Paris: Flammarion.

Propp, Vladimir. [1929] 1996. Morphology of the Folktale, trans. Laurence Scott. 2nd ed. Austin: University of Texas Press.

—_. [1946] 1983. Les racines historiques du conte merveilleux, trans. Lise Gruel-Apert. Paris: Gallimard.

Rooth, Anna Birgitta. [1951] 1980. The Cinderella Cycle. New York: Arno Press.

Sébillot, Paul. 2000. Contes populaires de la Haute-Bretagne. 2nd ed. Vol. 3, Contes des marins. Rennes: Terre de Brume.

Seifert, Lewis C., Catherine Velay-Vallantin, and Ruth Bottigheimer. 2006. Critical Exchanges: Comments on Fairy Tales and Oral Tradition. Marvels and Tales 20(2):276-84.

Soriano, Marc. 1977. Les contes de Perrault: Culture savante et traditions populaires. Rev. ed. Paris: Gallimard.

Swahn, Jan-Öjvind. 1955. The Tale of Cupid and Psyche (Aarne-Thompson 425 and 428). Lund: Gleerup.

Tenèze, Marie-Louise. 1973. Motifs stylistiques de contes et aires culturelles: Aubrac et France du Centre. In Mélanges de folklore et d’ethnographie dédiés à la mémoire d'Elisée Legros, pp. 45-83. Liège: Musée walon.

Tenèze, Marie-Louise, and Georges Delarue, eds. 2000. Nannette Lévesque, conteuse et chanteuse du pays des sources de la Loire. Paris: Gallimard.

Thompson, Stith. 1937. Review of Studien zur Wortsilbenstatistik der älteren estnischen Volkslieder, by Walter Anderson, and Zu Albert Wesselski's Angriffen auf die finnische folkloristische Forschungsmethode, by Walter Anderson. Journal of American Folklore 50(195):102.

_. [1946] 1977. The Folktale. Berkeley: University of California Press.

Uther, Hans-Jörg. 2004. The Types of International Folktales: A Classification and Bibliography, Based on the System of Antti Aarne and Stith Thompson. Vol. 1, Animal Tales, Tales of Magic, Religious Tales, and Realistic Tales. Helsinki: Academia Scientiarum Fennica.

Vaz da Silva, Francisco. 2000. Complex Entities in the Universe of Fairy Tales. Marvels and Tales 14(2):21943.

- 2002. Metamorphosis: The Dynamics of Symbolism in European Fairy Tales. New York: Peter Lang. Verdier, Yvonne. 1997. Little Red Riding Hood in Oral Tradition. Marvels and Tales 11(1-2):101-23.

Ward, Donald. 1994. The 1992 Archer Taylor Lecture: The German Connection: The Brothers Grimm and the Study of "Oral" Literature. Western Folklore 53(1):1-26.

Ziolkowski, Jan M. 2002. Old Wives’ Tales: Classicism and Anti-Classicism from Apuleius to Chaucer. The Journal of Medieval Latin 12:90-113.

- 2007. Fairy Tales from Before Fairy Tales: The Medieval Latin Past of Wonderful Lies. Ann Arbor: University of Michigan Press.

Zipes, Jack. 1993. The Trials and Tribulations of Little Red Riding Hood. 2nd ed. New York: Routledge. 